Agnieszka Pawełczyk ${ }^{l^{*}}$, Renata Welc-Falęciak², Anna Bajer ${ }^{2}$

\title{
SELECTED ASPECTS OF HELMINTH INFECTIONS (Schistosoma sp., Ascaris lumbricoides, Strongyloides stercoralis) IN INDIVIDUALS DIAGNOSED WITH HUMAN IMMUNODEFICIENCY VIRUS (HIV) INFECTION*
}

\section{WYBRANE ASPEKTY ZARAŻEŃ HELMINTAMI (Schistosoma sp., Ascaris lumbricoides, Strongyloides stercoralis) U OSÓB ZE STWIERDZONYM ZAKAŻENIEM LUDZKIM WIRUSEM NIEDOBORU ODPORNOŚCI (HIV)*}

\author{
${ }^{1}$ Medical University of Warsaw, Department of Immunopathology of Infectious \\ and Parasitic Diseases, Warsaw, Poland \\ ${ }^{2}$ University of Warsaw, Faculty of Biology, Department of Parasitology \\ ${ }^{1}$ Warszawski Uniwersytet Medyczny, Zakład Immunopatologii Chorób Zakaźnych i Pasożytniczych \\ ${ }^{2}$ Warszawski Uniwersytet Medyczny, Instytut Zoologii, Zakład Parazytologii
}

\begin{abstract}
Co-infections of HIV and other pathogens constitute an important clinical and epidemiological problem. Many studies have played attention to opportunistic co-infections due to the fact that they are used as an indicator for development of AIDS and are present on the all continents. However, in HIV-infected patients helminth infections, which are not aetiologic agents of opportunistic infections, are becoming more and more important. Prevalence of helminth infection depends on parasite species, environmental and socio-economic factors, therefore the results of published research mainly refer to populations of patients in developing countries and endemic regions.

In many cases, pathogenetic mechanisms of these co-infections are not fully recognized, and the obtained results are ambiguous.

Thus we performed literature review concerning the course and implications of co-infections with three selected helminth species, of different tissue/organ tropism (Ascaris lumbricoides, Strongyloides stercoralis, Schistosoma sp.), in patients with HIV infection.
\end{abstract}

Key words: HIV, helminths, pathogen, parasites, coinfections

\section{STRESZCZENIE}

Współzakażenia HIV i innymi patogenami stanowią poważny problem kliniczny i epidemiologiczny. Wiele badań poświęcono zakażeniom oportunistycznym, ze względu na fakt, iż stanowią one wskaźnik rozwoju AIDS i występują na wszystkich kontynentach.

Coraz bardziej znaczące są jednak koinfekcje HIV z helmintami, które nie są czynnikami etiologicznymi zakażeń/zarażeń oportunistycznych. Częstość infekcji uwarunkowana jest miejscem występowania danego gatunku pasożyta oraz czynnikami socjoekonomicznymi, dlatego też wyniki publikowanych prac badawczych odnoszą się przede wszystkim do populacji pacjentów zamieszkujących kraje rozwijające się i rejony endemiczne. W wielu przypadkach mechanizmy patogenetyczne tych koinfekcji nie są do końca poznane, a uzyskiwane wyniki są niejednoznaczne.

Celem pracy jest przegląd aktualnego stanu wiedzy, dotyczącego przebiegu i konsekwencji koinfekcji HIV i wybranymi gatunkami pasożytów: Ascaris lumbricoides, Strongyloides stercoralis, Schistosoma sp.

Słowa kluczowe: HIV, helminty, pasożyty, patogen, wspótzakażenia

\footnotetext{
*The study was funded by the Ministry of Science and Higher Education (MNISW) Iuventus Plus grant nr IP2014050373 / *Sfinansowano z funduszy Ministerstwa Nauki i Szkolnictwa Wyższego (MNISW) grant Iuventus Plus nr IP2014050373

(C) National Institute of Public Health - National Institute of Hygiene / Narodowy Instytut Zdrowia Publicznego - Państwowy Zakład Higieny
} 


\section{INTRODUCTION}

One of serious health problems among people with HIV infection are co-infections caused by other pathogens, such as viruses, bacteria, single-celled and multicellular parasites and fungi. The prevalence of co-infections is $20-60 \%$, and usually co-infections involve pathogens occurring in the same geographical regions (1).

Many papers deal with infections that are indicators of AIDS diagnosis and are used to determine the stage of the disease (2). There is also an interesting group of pathogens that are not aetiological factors of opportunistic infections/infestations including, among others, helminths.

Helminths are parasitic worms that form a diverse and clinically significant group of organisms. The prevalence of helminth infection depends on geographical range of a certain parasite and socioeconomic factors. Therefore, the results of the majority of published studies pertain to patient populations residing in developing countries and endemic regions (i.e. Kenya, Cameroon, Congo, Ethiopia, Zimbabwe, Iran, Venezuela, Nigeria, China) or present case reports of single patients, migrating e.g. to Italy or Spain (3-9).

\section{WPROWADZENIE}

Jednym $\mathrm{z}$ poważnych problemów zdrowotnych osób zakażonych HIV są koinfekcje wywołane innymi patogenami, takimi jak wirusy, bakterie, pasożyty jedno- i wielokomórkowe oraz grzyby. Częstość współzakażeń wynosi $20-60 \%$ i zwykle dotyczy patogenów występujących na tych samych obszarach geograficznych (1).

Wiele prac poświęcono zakażeniom, które stanowią wskaźnik rozpoznania i określenia stopnia zaawansowania AIDS (2). Interesującą grupę patogenów stanowią także te, które nie są czynnikami etiologicznymi zarażeń oportunistycznych, $\mathrm{m}$. in. helminty.

Helminty są to robaki pasożytnicze, stanowiące zróżnicowaną i istotną klinicznie grupę organizmów. Częstość zarażeń uwarunkowana jest zasięgiem geograficznym danego pasożyta oraz czynnikami socjoekonomicznymi, dlatego też wyniki publikowanych prac badawczych odnoszą się do populacji pacjentów zamieszkujących kraje rozwijające się i rejony endemiczne (Kenia, Kamerun, Kongo, Etiopia, Zimbabwe, Iran, Wenezuela, Nigeria, Chiny) lub przedstawiają opisy pojedynczych przypadków, pacjentów migrujących np. do Włoch, czy Hiszpanii (Ryc.1); (3-9).

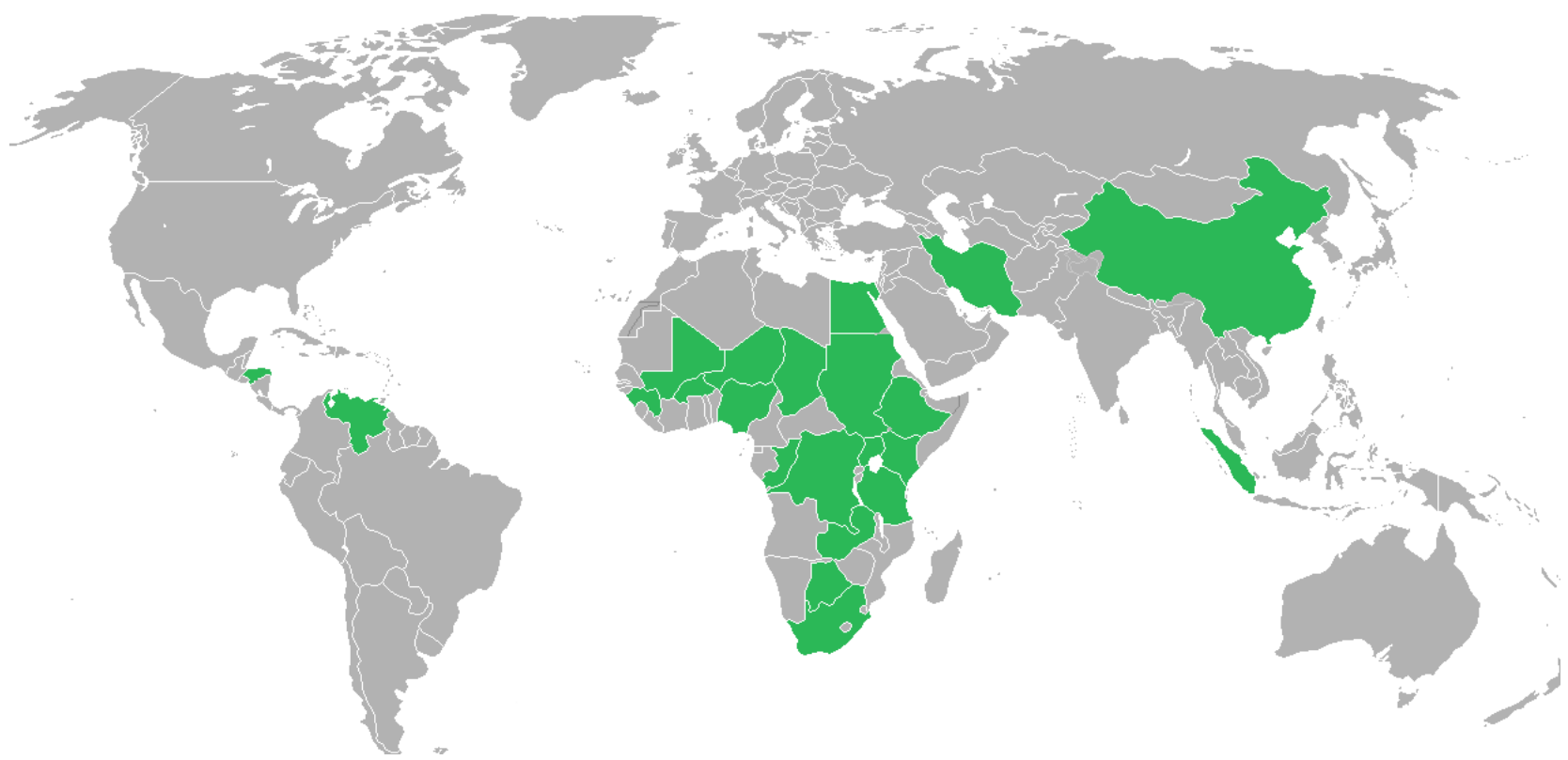

Fig. 1. The regions with the highest prevalence of helminth (A. lumbricoides, S. mansoni, S. stercoralis) and HIV co-infections. Ryc. 1. Obszary o najczęstszym występowaniu współzarażeń helmintami (A. lumbricoides, S. mansoni, S. stercoralis i HIV.

In many cases, pathogenetic mechanisms of these co-infections are not fully recognized, and the obtained results are ambiguous or contradictory.

The purpose of this work was to review the current knowledge on the course and consequences of coinfections with selected (differing with respect to location and parasitism pattern) helminth species most commonly accompanying HIV infection.
W wielu przypadkach mechanizmy patogenetyczne tych współzarażeń nie są do końca poznane, a uzyskiwane wyniki są niejednoznaczne lub sprzeczne.

Celem pracy jest analiza aktualnego stanu wiedzy na temat przebiegu i konsekwencji współzarażeń wybranymi (różniącymi się lokalizacją i sposobem pasożytowania), gatunkami helmintów, najczęściej towarzyszącymi zakażeniu HIV. 


\section{THE CONSEQUENCES OF PARASITE AND HIV CO-INFECTIONS}

HIV infection continues to pose a significant epidemiological and clinical problem. It is estimated to affect about 35 million people, with annual mortality of 1.5 million $(2,5,10)$. Introduction of combined antiretroviral therapy has fundamentally changed prognosis of the infected patients (11). Significant decrease of mortality after AIDS diagnosis was observed - from $79.5 \%$ to $62 \%$. At present, HIV infection is considered a chronic disease, and a consequence of this fact is the increase of virus carriers observed in the society.

The course of co-infection with HIV and other pathogens is different than the course of HIV infection alone or particular other pathogen alone. The reasons are either the immune system disorders resulting from CD4 T lymphocyte (CD4 TL) dysfunction as a consequence of HIV infection, as well as interactions between HIV and other pathogens $(11,12)$. The following changes are observed: aggravation of the course of viral infections and earlier development of cancers (e.g. HIV and HPV [human papilloma virus]); enhanced HIV replication (e.g. during infections with HIV and HHV8 [human herpesvirus type 8] or HIV and Plasmodium sp.); or HIV replication inhibition (HIV and Schistosoma spp.); (13-16).

\section{MULTICELLULAR PARASITE INFECTIONS}

More than $25 \%$ of people are infected with one or more helminth species, belonging mainly to the Platyhelminthes (trematodes, tapeworms) and Nemathelminthes (ascarids, nematomorpha) phyla (26). In Sub-Saharan Africa, prevalence of infection with Ascaris, Ancylostoma and Trichuris spp. is 22\%$25 \%, 29$ and $24 \%$, respectively $(1,20-23)$.

The results of a study by Fekadu et al. (17) show that prevalence of intestinal parasites was $37.3 \%$ in 343 patients with HIV/AIDS, and the fraction of patients infected with helminths $(22.7 \%)$ was higher than patients infected with protozoa (14.6\%).

One of clinical symptoms accompanying helminth infection is acute or chronic diarrhoea, severity of which depends on the genus/species of the parasite and on the patient immune system condition $(23,24)$. In the study conducted by Fekadu et al., 57\% of HIV/AIDS patients infected with intestinal parasites had chronic diarrhoea, whereas acute diarrhoea was observed in $3.4 \%$ of them (17). It is interesting that in many cases the course of infections with intestinal parasites such as A. lumbricoides, Taenia spp. or S. stercoralis was independent of patient's immune status (determined by CD4 TL counts), and diarrhoea was not always the only clinical symptom.

\section{KONSEKWENCJE WSPÓŁZARAZEŃ PASOŻYTAMI I HIV}

Zakażenie HIV stanowi nadal istotny problem epidemiologiczny i kliniczny. Szacuje się, że dotyczy ok. $35 \mathrm{mln}$. ludzi, których $1,5 \mathrm{mln}$ rocznie umiera $(2,5,10)$. Wprowadzenie skojarzonej terapii antyretrowirusowej zmieniło zasadniczo rokowanie osób zakażonych (11). Zaobserwowano znaczący spadek śmiertelności po rozpoznaniu AIDS z 79,5\% do 62\%. Obecnie zakażenie HIV uważa się za chorobę przewlekłą, czego konsekwencją jest obserwowany w społeczeństwie wzrost liczby nosicieli tego wirusa (11).

Przebieg współzarażeń patogenami i HIV różni się od przebiegu zakażenia tylko HIV, czy pojedynczymi patogenami. Przyczyną jest zaburzenie układu immunologicznego, u którego podłoża leży dysfunkcja limfocytów T CD4 (LT CD4), będąca następstwem zakażenia HIV oraz wzajemne interakcje pomiędzy HIV i innymi patogenami $(11,12)$. Obserwowane zjawiska dotyczą: zaostrzenia przebiegu zakażeń wirusowych i szybszej progresji do rozwoju nowotworu (np. HIV i HPV (wirus brodawczaka ludzkiego)); nasilenia replikacji HIV (np. podczas zakażeń HIV i HHV8 (ludzki herpeswirus typu 8) czy HIV i Plasmodium sp.)); czy zahamowania replikacji HIV (HIV i Schistosoma sp.);(13-16).

\section{ZARAŻENIA PASOŻYTAMI WIELOKOMÓRKOWYMI}

Ponad 25\% ludzi zarażonych jest jednym lub więcej gatunkami robaków, należącymi głównie do typów Platyhelminthes (przywry, tasiemce) oraz Nemathelminthes (glisty, nitnikowce) (26). Na obszarach Afryki Subsaharyjskiej, odsetek osób zarażonych Ascaris, Ancylostoma oraz Trichuris spp. wynosi odpowiednio $22 \%-25 \%, 29 \%$ oraz $24 \%(1,20-23)$.

Wyniki badań prowadzonych przez Fekadu i wsp. (17) wskazują, że częstość występowania pasożytów jelitowych wynosiła $37,3 \%$, u 343 pacjentów z HIV/ AIDS, przy czym odsetek pacjentów zarażonych helmintami (22.7\%) był wyższy niż u osób zarażonych pierwotniakami (14.6\%).

Jednym z objawów klinicznych towarzyszących robaczycom są ostre lub przewlekłe biegunki, których nasilenie zależy od rodzaju/gatunku pasożyta i kondycji immunologicznej pacjenta $(23,24)$. W badaniach prowadzonych przez Fekadu i wsp. $(23,24)$ u $57 \%$ pacjentów z HIV/AIDS i zarażonych pasożytami jelitowymi stwierdzano przewlekłą biegunkę, podczas gdy u 3,4\% obserwowano biegunkę ostrą (17). Interesujące jest, że przebieg zarażeń pasożytami jelitowymi, takimi jak $A$. lumbricoides, Taenia spp. czy $S$. stercoralis w wielu przypadkach był niezależny od statusu immunologicznego pacjenta (określony liczbą LT CD4), przy czym biegunka 
Abdominal pain, nausea and persistent subfebrile state were also frequently observed $(17,23,24)$. The obtained results show that parasitic infection may be suspected in patients with HIV also if chronic diarrhoea is absent and CD4 TL counts are relatively high.

\section{SELECTED ASPECTS OF THE COURSE OF PARASITIC INFECTION}

A modulatory effect of the parasite on the immune system of the host is observed in the course of parasitic infections, in particular in case of intestinal parasites. Disturbances of the immune response (hypersensitivity, autoimmunisation, deficiency) occur most commonly, which favours both parasite survival in the organism of the host and development of other infections.

Many parasitic infections (Taenia, A. lumbricoides in an early phase of infestation) may occur without typical clinical symptoms and these parasites are eliminated only through the action of the immune system without the need to use any treatment $(25,26)$. Other species, e.g. E. multilocularis, S. stercoralis, Schistosoma, Ascaris, have complex life cycles that lead to severe pathologies caused by disturbances of organ functions (caused by growing parasites), blood pressure increase and blood vessel obstruction (27). Migration of parasites (e.g. Schistosoma, Toxocara spp.) during their life cycle may lead to direct mechanical tissue damage or to injuries caused by immune reactions in the mechanism of hypersensitivity of all types $(28,29)$.

In the course of long-term infections with some helminth species, e.g. A. lumbricoides or Toxocara canis, stimulation of the immune system by antigens results in its strong activation leading to inflammatory changes, e.g. in the skin, lungs, liver, intestines or central nervous system $(22,30)$. Development of local allergic reactions, in the form of eosinophilia (e.g. eosinophilic pneumonia observed during $S$. stercoralis infection) or joint oedema (during Ascaris sp. infection) are noted (1,30,31,32).

Modulation of the immune system in the course of some parasitic infection may contribute to activation of HIV life cycle, including its replication. It was observed that increased expression of CCR5 (cysteinecysteine chemokine receptor 5) on the surface of CD4 TL occurs during infection with Trichuris sp. that facilitates HIV 'anchorage' on the surface of the cell and virus penetration into the cell $(29,30)$.

\section{THE COURSE OF PARASITE AND HIV CO-INFECTIONS}

The most severe course of co-infections is observed in the developing countries, in the tropical and subtropical regions, in the area of Sub-Saharan Africa [Fig. 1]; $(17,27,34)$. Worm infections, in particular nie zawsze była jedynym objawem klinicznym. Często obserwowano także ból brzucha, nudności, utrzymujący się stan podgorączkowy. Uzyskane wyniki wskazują, że zarażenia pasożytami można podejrzewać u pacjentów zakażonych HIV, także przy braku przewlekłej biegunki oraz pomimo stosunkowo wysokiej liczby LT CD4.

\section{WYBRANE ASPEKTY PRZEBIEGU ZARAŻEŃ PASOŻYTNICZYCH}

W przebiegu zarażeń pasożytniczych, zwłaszcza pasożytami jelitowymi, obserwuje się modulujący wpływ pasożyta na układ immunologiczny żywiciela. Najczęściej dochodzi do zaburzeń odpowiedzi immunologicznej (nadwrażliwość, autoimmunizacja, niedobór), co sprzyja zarówno utrzymywaniu się pasożyta w organizmie żywiciela, jak i rozwojowi innych zakażeń, czy zarażeń.

Wiele zarażeń pasożytniczych (Taenia, A. lumbricoides we wczesnej fazie zarażenia) może przebiegać bez charakterystycznych objawów klinicznych i do ich eliminacji dochodzi jedynie poprzez działanie układu odpornościowego, bez konieczności stosowania leczenia $(25,26)$. Inne gatunki np. E. multilocularis $S$. stercoralis, Schistosoma, Ascaris charakteryzuje złożony przebieg cyklu rozwojowego, prowadzący do ciężkich patologii spowodowanych zaburzeniem funkcji narządów wewnętrznych przez rosnące pasożyty, wzrostem ciśnienia krwi, zaczopowaniem naczyń krwionośnych (27). Migracje pasożytów (np. Schistosoma, Toxocara spp.) podczas ich cyklu życiowego mogą prowadzić do bezpośrednich, mechanicznych uszkodzeń tkanek lub uszkodzeń spowodowanych reakcjami immunologicznymi w mechanizmie wszystkich typów nadwrażliwości $(28,29)$.

W przebiegu długotrwałych zarażeń niektórymi gatunkami helmintów np. glistą ludzką czy glistą psią, konsekwencją stymulacji antygenami układu immunologicznego jest jego silne pobudzenie, prowadzące do zmian zapalnych, np. w skórze, płucach, wątrobie, jelitach, czy ośrodkowym układzie nerwowym $(22,30)$ . Obserwowano rozwój lokalnych reakcji alergicznych w postaci eozynofilii np. eozynofilowe zapalenie płuc podczas zarażenia węgorkiem S. stercoralis, czy obrzęk stawów (podczas zarażenia glistą Ascaris sp.); $(1,30,31,32)$.

Modulacja układu immunologicznego w przebiegu niektórych zarażeń pasożytniczych może przyczynić się do aktywacji cyklu życiowego HIV, w tym jego procesów replikacyjnych. Podczas zarażenia włosogłówką Trichuris sp. zaobserwowano wzrost ekspresji receptora CCR5 (cysteine-cysteine chemokine receptor 5) na powierzchni LT CD4, co ułatwia ,zakotwiczenie" się HIV na powierzchni komórki i wniknięcie wirusa do jej wnętrza $(29,33)$. 
Schistosoma spp., significantly contribute to the increasing risk of vertical HIV transmission - by 15 $45 \%$, and to the progression of HIV infection $(13,30)$. In this group of patients, AIDS development is observed twice as frequently as in case of monoinfection (25).

The underlying factors of pathogenetic mechanisms involved here are, first of all, impaired immune system function resulting from its prolonged activation during chronic or recurrent infections. Often is observed: activation of pro-inflammatory cytokine action, disturbances of proliferation and distribution of immune cells, enhanced expression of HIV receptors (CCR5, CXC-R4) and a shift of the type of immune response from Th1 ( $\mathrm{T}$ helper lymphocytes type 1) to Th2 ( $\mathrm{T}$ helper lymphocytes type 2), with helminth-induced activation of type 2 cytokine release (IL4 [interleukin 4], IL5 [interleukin 5], IL13 [interleukin 13]) and feedback inhibition of type Th1 response $(25,35,36,37,38)$. A consequence of this shift is, among others, a high level of IgE antibodies (immunoglobulin E), which may in turn be a factor favouring HIV replication $(7,39,40)$. This mechanism was well-recognized in animal models (7).

Changes in the immune system caused by Ascaris sp. infection and their significance for the course of HIV infection were studied by Mkhize-Kwitshana (41). Prevalence of intestinal worms in the analysed group of 200 patients ranged from 40 to $60 \%$. These patients presented high titres of IgE antibodies, irrespective of HIV infection. However, relatively high physiological IgE antibody titres are typical for African population $(40,42,43)$.

Other consequences of intestinal parasitic infections are also disturbances of $\mathrm{T}$ lymphocyte counts (36). A statistically significant association was reported between CD4 TL counts and the prevalence of parasitic infestations, and particularly with parasitaemia severity (26). People with higher CD4 TL counts (more than 500 cells $/ \mathrm{ml}$ ) were more frequently infected with helminths than people with lower cell counts (20). However, people with CD4 TL counts below 200 cells $/ \mathrm{ml}$ and impaired immune response have also poorer physical condition that negatively impacts their professional activity (e.g. involvement in agricultural works) and likely results with lower exposition to helminth infective stages in endemic regions (20).

Reverse associations have been observed in Uganda, among women infected with HIV-1. Low CD4 lymphocyte levels correlated with a high prevalence of Ancylostoma duodenale infections (16). A decrease of CD4 cell counts was also observed during heavy Strongyloides sp. infection (43).

During intestinal parasite infections, disturbances of immune system function are often observed which results in decreased control of HIV infection as reported by Vouking et al. (2014), contributing to progression of HIV infection observed in patients (1).

\section{PRZEBIEG WSPÓŁZARAŻENIA PASOŻYTAMI I HIV}

Najcięższy przebieg koinfekcji obserwowany jest wśród ludności w krajach rozwijających się, w regionie tropikalnym i subtropikalnym, na terenach Afryki Subsaharyjskiej (Ryc.1); (17,27,34). Zarażenia robakami, zwłaszcza Schistosoma sp., w istotny sposób przyczyniają się do wzrostu ryzyka transmisji wertykalnej HIV o $15 \%$ - $45 \%$ oraz progresji zakażenia HIV (13, 30 ). W tej grupie pacjentów rozwój AIDS obserwuje się dwukrotnie częściej niż przy monoinfekcji (25).

U podłoża mechanizmów patogenetycznych leżą przede wszystkim zaburzenia funkcji układu immunologicznego, powstałe na skutek jego długotrwałej aktywacji podczas przewlekłych lub nawracających zarażeń. Związane są one z: aktywacją prozapalnego działania cytokin, zaburzeniem proliferacji i dystrybucji komórek odpornościowych, zwiększoną ekspresją receptorów HIV (CCR5, CXC-R4) oraz przesunięciem typu odpowiedzi immunologicznej z Th1 (limfocyty T pomocnicze typu 1) na Th2 (limfocyty $T$ pomocnicze typu 2), z wywołaną przez helminty aktywacją wydzielania cytokin typu 2 (IL4 (interleukina 4), IL5 (interleukina 5), IL13 (interleukina 13)) i zwrotnego hamowania odpowiedzi typu Th1 $(25,35,36,37,38)$. Konsekwencją tego przesunięcia jest $\mathrm{m}$. in. obserwowany wysoki poziom przeciwciał klasy IgE (immunoglobulina E), co może być czynnikiem sprzyjającym replikacji HIV $(7,39,40)$. Mechanizm ten został dobrze zobrazowany na modelach zwierzęcych (7).

Zmiany w układzie immunologicznym wywołane zarażeniem Ascaris sp. i ich znaczenie dla przebiegu zakażenia HIV badała Mkhize-Kwitshana (41). Wykazano, że częstość występowania zarażeń robakami jelitowymi w analizowanej grupie 200 pacjentów wynosiła od $40 \%$ do $60 \%$. Pacjenci charakteryzowali się wysokim mianem przeciwciał IgE, niezależnie od zakażenia HIV. Może to jednak wynikać z faktu, że stosunkowo wysokie, fizjologiczne miano przeciwciał IgE jest charakterystyczne dla rasy afrykańskiej $(40,42,43)$.

Następstwem zarażenia pasożytami jelitowymi są również zaburzenia liczby limfocytów T (36). Wykazano istotny statystycznie związek pomiędzy liczbą LT CD4 a częstością zarażeń pasożytniczych, ze szczególnym uwzględnieniem intensywności parazytemii (26). Wyniki prowadzonych badań wskazują, że osoby z wyższą liczbą komórek LT CD4 (ponad 500 kom/ $\mathrm{ml})$ są częściej zarażone helmintami niż osoby z niższą liczbą komórek (20). Tłumaczyć to można tym, że osoby z liczbą LT CD4 poniżej $200 \mathrm{kom} / \mathrm{ml}$ i związanymi z tym zaburzeniami układu immunologicznego, cechuje m.in. słabsza kondycja fizyczna, co przekłada się na mniejszą aktywność zawodową (np. rzadszą pracę w polu) i w związku z tym mniejszą ekspozycję na zarażenie helmintami w rejonach endemicznych (20). 


\section{CO-INFECTION WITH SCHISTOSOMA MANSONI/HEMATOBIUM AND HIV}

It is estimated that schistosomiasis affects $230 \mathrm{mln}$ people worldwide, $90 \%$ of them live in the Sub-Saharan Africa (44). Regions of high endemia are observed in Ethiopia, Nigeria, RSA, Zimbabwe or Zambia. The proportion of infected individuals exceeds $50 \%$ and in such regions as Mozambique or Madagascar it may be much higher $(10,45,46)$. The estimated HIV infection prevalence in these countries ranges $15 \%-28 \%$.

Two factors influencing occurrence of HIV and S. mansoni co-infection are patient age and sequel of infections, however, the reported results are equivocal $(47,48,49)$. In the case of children, HIV is usually the primary infection (e.g. as a result of vertical transmission), followed by Schistosoma sp. infection. The opposite is observed in adults (40).

Depending on the situation, different effects on immune system dysfunction, pathogen-induced modulation and efficacy of co-infection treatment may be observed (50,51). Studies conducted by Ayash-Raskovsky et al. (2007) on rhesus monkeys infected with SHIV (simian-human immunodeficiency virus, analogous to HIV) and subsequently infected with $S$. mansoni revealed a significant increase in virus replication and faster disease progression than in animals not infected with parasite (50). Studies on mice with decreased CD4 TL counts infected with $S$. mansoni and then treated with antiparasitic drugs reported significantly weaker output of the antiparasitic treatment, as compared with animals with normal immune system (51).

In patients primarily infected with flukes and subsequently infected with HIV fewer parasite eggs are expelled $(45,52)$. These results suggest that preserved function of the immune system, expressed as normal CD4 TL counts, is necessary for the normal reproduction and completion of the fluke life cycle.

Other studies on co-infections revealed that $S$. mansoni infection accelerates HIV progression in coinfected individuals $(22,53)$. Chronic immune system activation and activation of Th2-mediated response are observed in the course of fluke infections which favours mycobacterial and viral infections, including HIV infection $(28,48)$. During infection with $S$. haematobium mucous membranes of the genital tracts get damaged and become more susceptible to HIV infection $(28,54,55)$. Infiltration with CD4 TL, macrophages, CD68 cells (antigen of cell differentiation 68) is observed, as well as apoptosis activation. Schistosoma haematobium induces haemorrhagic, inflammatory and then hypertrophic and papillary changes in the walls of the bladder and in other pelvic organs $(54,55)$. Dendritic cells become activated via signalling pathway modulation $(54,55)$.
Odwrotne zależności obserwowano w Ugandzie, wśród kobiet zakażonych HIV-1. Niski poziom limfocytów CD4 korelował tutaj z wysoką częstością zarażenia tęgoryjcami Ancylostoma duodenale (16). Spadek liczby komórek CD4 obserwowano także w czasie nasilonego zarażenia węgorkami Strongyloides sp. (43).

Podczas zarażeń pasożytami jelitowymi obserwuje się zaburzenia funkcji układu immunologicznego, czego konsekwencją jest obniżenie jego efektywności w ograniczeniu zakażenia HIV, co wykazali w badaniach Vouking i wsp. (2014), thumacząc obserwowaną u pacjentów progresję zakażenia (1).

\section{WSPÓŁZARAŻENIA \\ SCHISTOSOMA MANSONI/HEMATOBIUM I HIV}

Szacuje się, że schistosomoza występuje u $230 \mathrm{mln}$ ludzi na świecie, z których 90\% żyje w regionie Afryki Subsaharyjskiej (44). Obszary o wysokiej endemii obserwuje się w Etiopii, Nigerii, RPA, Zimbabwe czy Zambii. Odsetek zarażonych osób przekracza 50\%, a może być znacznie wyższy na obszarach takich jak Mozambik czy Madagaskar $(10,45,46)$. Częstość zakażeń HIV w tych krajach szacuje się od $15 \%$ do $28 \%$.

W przebiegu koinfekcji HIV i S. mansoni wydaje się, że istotne znaczenie ma kolejność zakażenia/zarażenia oraz wiek pacjenta, jednakże uzyskiwane wyniki nie są jednoznaczne $(47,48,49)$. U dzieci, najczęściej pierwszym zakażeniem jest HIV (np. w wyniku transmisji pionowej), później Schistosoma sp., u osób dorosłych jest odwrotnie (40).

W zależności od sytuacji można obserwować różny efekt dysfunkcji i modulacji układu immunologicznego przez patogeny oraz zróżnicowaną skuteczność leczenia współzakażeń $(50,51)$. W badaniach prowadzonych przez Ayash-Raskovsky i wsp. (2007) na małpach (rezusy) zakażonych SHIV (simian-human immunodeficiency virus, analogiczny do HIV), które następnie zarażano cerkariami Schisosoma mansoni, zaobserwowano znaczący wzrost replikacji wirusa i szybszą progresję choroby w porównaniu do zwierząt niezarażanych pasożytami (50). Badania myszy z obniżoną liczbą LT CD4, zarażonych $S$. mansoni, a następnie leczonych przeciwpasożytniczo, wskazały na znacznie słabszy efekt leczenia przeciwpasożytniczego $\mathrm{w}$ porównaniu do zwierząt $\mathrm{z}$ prawidłowo funkcjonującym układem immunologicznym (51).

U pacjentów pierwotnie zarażonych przywrami, a następnie zakażonych HIV, obserwuje się mniej wydalanych jaj pasożytów $(45,52)$. Uzyskane wyniki sugerują, że dla prawidłowego przebiegu cyklu życiowego przywry (zachowania płodności pasożyta), konieczne jest zachowanie aktywności układu immunologicznego, wyrażonej prawidłową liczbą LT CD4.

Badania wskazują, że $S$. mansoni przyspiesza progresję HIV u osób współzakażonych $(22,53)$. Podczas 
The prevalence of HIV infection in women with genital schistosomiasis has been estimated to be three times as high as in women not infected with this parasite (55).

The results of studies conducted in Uganda by Sanya et al. (2015) in a group of 1412 patients did not clearly show that HIV infection favoured infection with $S$. mansoni $(56,57)$. However, it was found that the numbers of parasite eggs (per gram of the examined stool) were significantly lower in people co-infected with HIV, as compared to HIV-negative individuals (56,57).

Activation of Th2 TL-mediated immune response is more favourable for HIV replication than the Th1mediated one, which may explain the observed enhanced HIV replication during co-infections with parasites that activate Th2 type of immune response (57).

In children, much higher mortality values are observed and the effects of HIV and Schistosoma sp. infections are rather synergistic (42). Marked cachexia occurs, in the course of both viral and parasitic disease. Anaemia and disturbances of metabolic processes that play a key role in the normal development of children are the most common findings. This is confirmed by the results of cohort studies of children chronically infected with HIV and other pathogens (Pneumocistis jiroveci, Klebsiella pneumoniae, Mycobacterium tuberculosis), and also with parasites (e.g. Cryptosporidium, Toxoplasma spp.) in Zimbabwe and in South Africa $(6,34,40,48,49,59,60)$.

The studies on patients infected with S. mansoni (61) reported significant damage of the intestinal mucosa leading to malabsorption $(35,54)$. Understanding of these mechanisms, in particular in people with HIV and Schistosoma spp. co-infections may considerably improve patient prognosis and contribute to the higher efficacy of prevention.

Environmental and socio-economic factors play an important role in the failure of preventive activities, including no access to 'safe' water and sanitary facilities, failure to follow basic hygiene principles and low socio-economic status (61). There is a need to improve the knowledge on epidemiology, biology and transmission routes of pathogens/parasites in populations at risk. As far as HIV infection is concerned, risky sexual behaviour and intravenous drug use shall be pointed; for Schistosoma sp. it concerns the contacts with contaminated water during household or work activities (the fluke is widespread in fishing communities) (61).

Among numerous programmes on prevention of co-infections in HIV-infected patients promoted by the WHO, helminth infections got limited interest and have not yet been included into the group of so called 'multiple endemic diseases'. przebiegu zarażenia przywrą obserwuje się przewlekłą aktywację układu immunologicznego oraz aktywację odpowiedzi Th2 zależnej, co sprzyja zakażeniom mykobakteryjnym i wirusowym, w tym HIV $(28,48)$. Podczas zarażenia $S$. hematobium, dochodzi do uszkodzenia błony śluzowej narządów płciowych i wzrostu wrażliwości na zakażenie HIV $(28,54,55)$. Obserwuje się naciek ze strony LT CD4, makrofagów, komórek CD68 (antygen różnicowania komórkowego 68), a także aktywację apoptozy. S. haematobium wywołuje zmiany krwotoczne i zapalne, a potem przerostowe i brodawczakowe ścian pęcherza moczowego i innych narządów miednicy mniejszej $(54,55)$. Dochodzi do aktywacji komórek dendrytycznych, poprzez modulowanie ścieżek sygnałowych $(54,55)$. Oszacowano, że częstość zakażenia HIV u kobiet ze schistosomozą narządów płciowych była trzykrotnie wyższa niż u kobiet niezarażonych pasożytem (55).

Wyniki badań prowadzonych w Ugandzie przez $\mathrm{Sa}$ nya i wsp. (2015) w grupie 1412 pacjentów nie wykazały jednoznacznie, że zakażenie HIV sprzyja zarażeniu S. mansoni (56). Zaobserwowano natomiast, że liczba jaj pasożyta (liczona na gram badanego stolca) była znacząco niższa u osób zakażonych jednocześnie HIV w porównaniu do osób z inwazją pojedynczą $(56,57)$.

Aktywacja odpowiedzi immunologicznej zależnej od LT Th2 jest bardziej korzystna dla replikacji HIV, niż w odpowiedzi immunologicznej zależnej od Th1, co może thumaczyć obserwowany wzrost replikacji HIV podczas współzarażenia pasożytami aktywującymi odpowiedź immunologiczną typu Th2 (57).

W przypadku dzieci, obserwuje się znacznie wyższą śmiertelność i raczej działanie synergistyczne HIV i Schistosoma sp. (42). Dochodzi do znacznego wyniszczenia organizmu, zarówno w przebiegu choroby wirusowej, jak i pasożytniczej. Najczęściej obserwowana jest niedokrwistość oraz zaburzenie procesów metabolicznych, które odgrywają kluczową rolę w przebiegu prawidłowego rozwoju dzieci. Znajduje to potwierdzenie w wynikach badań kohortowych dzieci przewlekle zakażonych HIV i innymi patogenami (Pneumocistis jiroveci, Klebsiella pneumoniae, Mycobacterium tuberculosis), także pasożytami (np. Cryptosporidium sp, Toxoplasma sp.) w Zimbabwe oraz Afryce Południowej $(6,34,40,48,49,59,60)$.

Wyniki badań pacjentów zakażonych $S$. mansoni prowadzonych przez Jourdan i wsp. wskazywały na znaczne uszkodzenie komórek błony śluzowej jelita, prowadzące do zaburzeń wchłaniania $(31,48)$. Poznanie tych mechanizmów, zwłaszcza u osób z koinfekcją HIV i Schistosoma spp. może znacznie poprawić rokowania pacjentów i przyczynić się do podniesienia efektywności profilaktyki.

Istotną rolą w niepowodzeniu działań profilaktycznych przypisuje się czynnikom środowiskowym oraz socjoekonomicznym. Należy do nich brak dostępu do 


\section{CO-INFECTION WITH ASCARIS LUMBRICOIDES AND HIV}

The consequences of parasite infections depend to a large extent on the specific traits of parasite life cycle, e.g. time and migration route/localization of particular developmental stages (30). In the case of Ascaris sp. infections, larvae are released from ingested eggs in the intestines, then migrate to the blood vessels, bronchi and lung alveoli. Expectorated to the oral cavity, larvae are swallowed and reach the intestines again where they mature. Ascaris inhabits the intestine for a period of 13-15 months and then spontaneous recovery occurs. As much as several hundred of worms may live in the intestine at a time, which leads to an increased probability of re-infections and/or complications (e.g. ileus, appendicitis, pneumonia).

Respiratory tract diseases are a major cause of death in HIV-infected people (59). There is a wide spectrum of aetiological agents responsible for the development of respiratory disease; opportunistic pathogens (Aspergillus sp., Cryptococcus sp., Histoplasma sp. Coccidioides sp., CMV), but also parasitess, i.e. Toxoplasma sp., Strongyloides sp. $(2,6,15,18,34)$. As clinical symptoms and imaging results are often similar, it is often difficult to identify the agent of the disease, i.e. species of the pathogen $(59,62)$.

Ascaris sp. is not included in the group of opportunistic pathogens. The symptoms of infection in HIV-infected patients are similar to that in the HIVnegative individuals. In patients with marked immunity deficits, clinical symptoms involve commonly the pulmonary form of ascariasis (pulmonary eosinophilia); $(30,63)$. However, such cases are not frequently observed, even in endemic regions $(30,63)$. This is explained by rarely observable clinical symptoms and difficulties in accurate diagnosis of parasite infections $(30,63)$. Eosinophilic infiltrates and bronchiolitis are found in patients, but frequently these symptoms fail to be attributed to a parasite (30). During the first infection, in the phase of larvae migration, the result of stool examination for parasites may be false negative (at this stage the larvae may be found only in stomach content aspirates), which may mislead the diagnosis (30).

Pneumonia may be caused by the presence of migrating parasites (larvae) itself, but also by an excessively activated immune response, in the mechanism of type 1 hypersensitivity, which explains episodic asthma-like bronchial symptoms and peripheral eosinophilia $(30,63)$.

During Ascaris sp. infections there is an increase of CD4 and CD8 TL activation marker, as well as an increase in HLA DR activity. Expression of proinflammatory and regulatory cytokines (IL 1 $1 \beta$, IL10, IL 13) is observed (28). „bezpiecznej” wody, urządzeń sanitarnych, nieprzestrzeganie podstawowych zasad higieny oraz niski status społeczno-ekonomiczny (61). Konieczne jest upowszechnienie wiedzy dotyczącej epidemiologii, biologii i sposobów transmisji patogenów. W przypadku HIV chodzi o ryzykowne zachowania seksualne, dożylne zażywanie narkotyków, u Schistosoma sp. to kontakt ze skażoną wodą podczas prac domowych, czy czynności zawodowych (przywra szeroko rozpowszechniona w społecznościach rybackich); (61).

Wśród licznych programów zapobiegających koinfekcjom promowanym przez WHO, robaczyce stanowią temat poboczny i nie zostały uznane za tzw. „multiple endemic diseases”.

\section{WSPÓŁZARAŻENIE ASCARIS LUMBRICOIDES I HIV}

O konsekwencjach zarażeń pasożytniczych decyduje w znacznym stopniu specyfika cyklu rozwojowego pasożytów, np. miejsce i czas migracji poszczególnych stadiów rozwojowych (30). W zarażeniu Ascaris sp., po połknięciu jaj, w jelitach uwalniają się larwy, które wędrują do naczyń krwionośnych, oskrzeli i pęcherzyków płucnych. Odkrztuszane do jamy ustnej, po połknięciu ponownie dostają się do jelit, gdzie dojrzewają. Glista pasożytuje w jelicie przez okres 1315 miesięcy, po czym dochodzi do samowyleczenia. W jelicie może przebywać nawet kilkaset glist jednocześnie, przez co wzrasta prawdopodobieństwo ponownych zarażeń i/lub powikłań (np. niedrożność jelita, zapalenie wyrostka robaczkowego, zapalenie płuc).

U osób zakażonych HIV, choroby dróg oddechowych stanowią istotną przyczynę zgonów (59). Spektrum czynników etiologicznych jest szerokie i obejmuje, oprócz zakażeń oportunistycznych (Aspergillus sp., Cryptococcus sp., Histoplasma sp. Coccidioides sp, CMV), zarażenia pasożytnicze t.j. Toxoplasma sp., Strongyloides sp.; $(2,6,15,18,34)$. Ponieważ objawy kliniczne i wyniki badań radiologicznych są często podobne, trudno jest jednoznacznie określić przyczynę, tj. rodzaj patogenu $(59,62)$.

Glista Ascaris sp. nie jest zaliczana do patogenów oportunistycznych. Objawy zarażenia u pacjentów zakażonych HIV są podobne jak w populacji osób niezakażonych. U pacjentów ze znacznym upośledzeniem odporności, obserwowane objawy kliniczne częściej dotyczą postaci płucnej glistnicy (eozynofilia płucna); $(30,63)$. Nie są jednak często odnotowywane, nawet w rejonach endemicznych $(30,63)$. Thumaczy się to rzadko występującymi objawami klinicznymi i trudnościami w prawidłowym rozpoznaniu zarażenia $(30,63)$. U pacjentów obserwuje się nacieki eozynofiliów oraz zapalenie oskrzelików, często niekojarzone z występowaniem pasożyta (30). Podczas pierwszego zarażenia, $\mathrm{w}$ fazie migracji larw, wynik badania kału w kierunku obecności pasożyta może być fałszywie negatywny (na 


\section{CO-INFECTION WITH STRONGYLOIDES SP. AND HIV}

Strongyloides stercoralis is the aetiological agent of strongyloidiasis. It is estimated that about 30100 million people worldwide are infected with this parasite, mainly in tropical and subtropical regions (64). Co-infections with HIV and Strongyloides are common, affect $5-25 \%$ of population $(1,65,66)$.

The entire life cycle of the parasite may take place in the human body and, due to auto-infection, the disease may last for many years. In the majority of cases, the course of infection is asymptomatic (65). Clinical symptoms include abdominal pain and cutaneous symptoms. In case of a complicated strongyloidiasis, nausea, vomiting, diarrhoea, and colitis may also occur, which may result in weight loss and cachexia of the patient body. Respiratory symptoms are rarely observed $(43,67)$.

In immunodeficient people, including HIV-infected patients, strongyloidiasis may lead to death caused by parasite hyperinfection, by the mechanism of respiratory insufficiency $(27,68)$. These complications are observed in $87 \%$ of patients with co-infection $(27,68)$.

The most common clinical symptoms in patients with S.stercoralis and HIV co-infection include chronic diarrhoea, fever and persistent cough $(43,65)$. In years 1986-1987 the occurrence of S. stercoralis "hyperinfection" was one of AIDS diagnostic criteria $(69,70)$. Due to the lack of association between the prevalence of HIV and S. stercoralis infections in the endemic regions, it was concluded that HIV infection is not a risk factor for strongyloidiasis $(65,66,68,69)$. It was demonstrated that disturbances of cellular immune response observed during $S$. stercoralis infection and treatment with corticosteroids are the factors predisposing to the "hyperinfection" syndrome $(8,66,70)$. Patients have eosinophilia that is elicited by promotion of $\mathrm{Th} 2$ lymphocyte-mediated immune response, whose consequence is eosinophil recruitment to the areas populated by the parasites, in particular during their migration $(31,32)$.

Some studies suggest also the association between colitis caused by Strongyloides sp. and HIV infection; however, the pathogenetic mechanism seems to be complex and is not fully recognized $(65,69,71)$.

\section{THE EFFECT OF ANTIRETROVIRAL THERAPY (HAART) ON THE INCIDENCE OF CO-INFESTIONS}

Statistically significant decrease in prevalence of some parasite infections, e.g. T. trichura, A. lumbricoides and $S$. stercoralis, was observed among patients undergoing antiretroviral therapy, which suggests that tym etapie larwy można znaleźć np. tylko w aspiratach żołądka), co może przesądzić o rozpoznaniu (30).

Przyczyną zapalenia płuc może być tylko obecność migrujących pasożytów (larwy), a także nadmiernie pobudzona odpowiedź ze strony układu immunologicznego, w mechanizmie nadwrażliwości typu pierwszego, co thumaczy epizodyczne objawy oskrzelowe, przypominające astmę oraz obwodową eozynofilię $(30,63)$.

Podczas zarażenia Ascaris sp. dochodzi do wzrostu ekspresji markerów aktywacji LT CD4 oraz CD8, a także wzrostu aktywności HLA DR. Obserwuje się ekspresję cytokin prozapalnych i regulacyjnych (IL $1 \beta$, IL10, IL 13) (28).

\section{WSPÓŁZARAŻENIE STRONGYLOIDES sp. i HIV}

Strongyloides stercoralis jest czynnikiem etiologicznym węgorczycy. Szacuje się, że 30-100 milionów ludzi na świecie jest zarażonych tym pasożytem, głównie w rejonach tropikalnych i subtropikalnych (64). Częstość występowania współzarażenia HIV i Strongyloides jest powszechne, przy czym szacuje się na 5-25\% $(1,65,66)$.

Cały cykl rozwojowy pasożyta może się odbyć w organizmie człowieka, natomiast wskutek autozarażeń choroba może trwać wiele lat. Przebieg zarażenia w większości przypadków jest bezobjawowy (65). Wśród objawów klinicznych notowane są bóle brzucha i objawy skórne. W przypadku powikłanej węgorczycy, mogą wystąpić także nudności, wymioty, biegunka, zapalenie jelita grubego, co może być przyczyną utraty masy ciała i wyniszczenia organizmu pacjenta $(43,67)$. Rzadko obserwuje się objawy ze strony układu oddechowego.

U osób z obniżoną odpornością, w tym zakażonych HIV, strongyloidoza może prowadzić do śmierci wywołanej nadkażeniem („hiperinfekcja”) pasożytem, na skutek niewydolności oddechowej $(27,68)$. Częstość tych powikłań obserwuje się u 87\% pacjentów z koinfekcją $(27,68)$.

Najczęstsze objawy kliniczne w tej grupie pacjentów to przewlekłe biegunki, gorączka oraz uporczywy kaszel $(43,65)$. W latach 1986-1987 występowanie ,hiperinfekcji" Strongyloides stercoralis stanowiło jedno z kryteriów definiowania AIDS $(69,70)$. Ze względu na brak korelacji pomiędzy częstością zakażenia HIV a zarażeniem Strongyloides stercoralis na terenach endemicznych stwierdzono, że HIV nie jest czynnikiem ryzyka węgorczycy $(65,66,68,69)$. Wykazano, iż czynnikiem predysponującym do zespołu „hiperinfekcji” jest zaburzenie odpowiedzi immunologicznej typu komórkowego, obserwowane w przebiegu zarażenia Strongyloides stercoralis oraz leczenie kortykosteroidami $(8,66,70)$. U pacjentów występuje eozynofilia wywołana promowaniem odpowiedzi immunologicznej zależnej od limfocytów Th2, której konsekwencją jest rekrutacja eozynofilii do miejsc bytowania pasożytów, zwłaszcza podczas ich migracji $(31,32)$. 
improvement of the function of the immune system contributes to limitation/elimination of intestinal parasite infections $(2,7,20)$. The results of some studies revealed that, apart from a decrease in HIV viraemia levels, the HAART therapy causes a decrease in IgE antibody levels. This leads to a conclusion that HIV is one of the factors that promote IgE production $(39,60,72,73,74)$.

The use of antihelminthic drugs, e.g. albendazole, causes a shift of immunity type towards Th1, which is of key importance in the anti-HIV immune response (67). If anti-parasitic and anti-HIV therapies are used concurrently, better results of the antiretroviral therapy are achieved (2). Thus, massive deworming of HIV-infected patients should be accompanied by the implementation of HAART therapy $(73,75)$.

\section{CONCLUSIONS}

Helminth infections occupy an important place among the diseases occurring in HIV-infected people, in particular in the developing countries. Published research results reveal that there are reciprocal interactions between helminths and HIV, in particular via mechanisms that modulate the functions of the immune system, not necessarily related to suppression.

It is interesting that in patients on antiretroviral therapy a significant decrease in prevalence of several helminth species ( $T$. trichura, A. lumbricoides and $S$. stercoralis, Schistosoma spp.) was observed $(11,28,60,73)$. Improvement of patient immune system function plays thus an important role in limitation/ elimination of infections with the analysed parasite species. However, the socio-economic factors and the treatment of the primary disease that causes immunosuppression shall not be neglected $(2,76,77,78)$.

The study was funded by the Ministry of Science and Higher Education (MNISW) Iuventus Plus grant $\mathrm{nr}$ IP2014050373.

\section{REFERENCES}

1. Vouking MZ., Enoka P, Tamo CV, et al. Prevalence of intestinal parasites among HIV patients at the Yaoundé Central Hospital, Cameroon. Pan Afr Medic J 2014; 18: 2-5.

2. Nkenfou CN, Nana CT, Payne WK. Intestinal parasitic infections in HIV infected and noninfected patients in a low HIV prevalence region, West-Cameroon. PLoS One 2013; 8: 1-6.

3. Buonfrate D, Bisoffi Z, Abrescia F et al. CCM Strongyloides Study Group.: Epidemiology of Strongyloides stercoralis in Northern Italy, results of a multicentre case-control study, February 2013 to July 2014. Euro Surveill 2016; DOI: 10.2807/1560-7917.
Wyniki prowadzonych badań, wskazują także na związek pomiędzy zapaleniem jelita grubego, wywołanego zarażeniem Strongyloides sp. a zakażeniem HIV, przy czym mechanizm patogenetyczny wydaje się być złożony i nie jest poznany $(65,69,71)$.

\section{WPLYW TERAPII ANTYRETROWIRUSOWEJ (HAART) NA CZĘSTOŚĆ WSPÓŁZAKAŻEŃ}

U pacjentów poddanych terapii antyretrowirusowej obserwowano istotne statystycznie zmniejszenie częstości zarażenia niektórymi gatunkami pasożytów, np. T. trichura, A. lumbricoides oraz S. stercoralis, co sugeruje, że poprawa funkcji układu immunologicznego przyczynia się do ograniczenia i redukcji zarażeń pasożytami jelitowymi $(2,7,20)$. Wyniki niektórych badań wskazują, że skutkiem HAART, oprócz zmniejszenia poziomu wiremii HIV, jest spadek poziomu przeciwciał IgE. Stanowi to przesłankę, że HIV jest jednym z czynników aktywujących wytwarzanie IgE $(39,60,72,73,74)$.

Stosowanie leków przeciwko helmintom, np. albendazolu, powoduje przesunięcie typu odporności w kierunku Th1, która ma kluczowe znaczenie w odpowiedzi immunologicznej przeciwko HIV (60). Przy równoczesnym stosowaniu terapii skierowanej przeciwko zarażeniom pasożytami i HIV uzyskuje się lepszy efekt terapii antyretrowirusowej (2). Zatem masowe odrobaczanie pacjentów zakażonych HIV powinno być skorelowane z terapią HAART $(73,75)$.

\section{PODSUMOWANIE}

Robaczyce zajmują ważne miejsce wśród chorób występujących u osób zakażonych HIV, zwłaszcza w krajach rozwijających się. Wyniki publikowanych badań wskazują na istnienie wzajemnych oddziaływań pomiędzy helmintami a HIV, zwłaszcza przez mechanizmy modulujące funkcje układu immunologicznego, niekoniecznie związane z supresją.

Interesujące jest, że u pacjentów poddanych terapii antyretrowirusowej obserwowano istotne zmniejszenie częstości zarażenia niektórymi gatunkami helmintów pasożytniczych (T. trichura, A. lumbricoides oraz S. stercoralis, Schistosoma spp.) $(11,28,60,73)$. Poprawa działania układu immunologicznego pacjenta odgrywa więc istotną rolę w ograniczeniu i redukcji zarażeń analizowanymi gatunkami pasożytów. Nie należy jednak zapominać o istotnym wpływie czynników socjoekonomicznych oraz leczeniu choroby podstawowej, wywołującej immunosupresję $(2,76,77,78)$.

Sfinansowano z funduszy Ministerstwa Nauki i Szkolnictwa Wyższego (MNISW) grant Iuventus Plus $n r$ IP2014050373. 
4. Ekejindu IM, Ele PU, Okonkwo SO, et al. Intestinal parasitic infection among HIV-seropositive and HIV-seronegative individuals at Nnewi, South Eastern Nigeria. World J Med Sci 2010; 5: 71-73.

5. Kipyegen CK, Shivairo RS, Odhiambo RO. Prevalence of intestinal parasites among HIV patients in Baringo, Kenya. Pan Afr Med J 2013;13: 1-13.

6. Lehman LG, Kangam L, Mbenoun ML, et al. Intestinal parasitic and Candida infection associated with HIV infection in Cameroon. J Infect Dev Ctries 2013; 7:1337-43.

7. Mascarello M, Gobbi F, Angheben A, et al. Prevalence of Strongyloides stercoralis infection among HIV-positive immigrants attending two Italian hospitals, from 2000 to 2009. Ann Trop Med Parasitol 2011; 105: 617-623.

8. Nabha L, Krishnan S, Ramanathan R, et al. Prevalence of Strongyloides stercoralis in an urban US AIDS cohort. Path Glob Health 2012; 106: 238-44.

9. Salvador F, Pahissa A, et al. Tropical diseases screening in immigrant patients with human immunodeficiency virus infection in Spain. Am J Trop Med Hyg 2013; 881196-1202.

10. WHO/UNAIDS/UNICEF. Global HIV/AIDS response: Epidemic updates and health sector progress towards universal access. Progress report 2011; 1: 1-164.

11. Maartens G, Celum C, Lewin SR. HIV infection: epidemiology, pathogenesis, treatment, and prevention. Lancet. 2014; 384: 258-271.

12. Tiberi S, Carvalho ACC, Sulis G, et al. The cursed duet today: tuberculosis and HIV-coinfection. Press Med 2017; 46: 23-39.

13. Beyene HB, Mulualem T, Disassa H, et al. Concurrent Plasmodium infection, anemia and their correlates among newly diagnosed people living with HIV/AIDS in Northern Ethiopia. Act Trop 2017; 169: 8-13.

14. Cavallin L, Goldschmidt-Clermont P, Mesri EA. Molecular and cellular mechanisms of KSHV oncogenesis of Kaposi's sarcoma associated with HIV/ AIDS 2014 PLoS Pathog 2014; DOI: 10.1371/journal.ppat.1004154.

15. Courville EL, Sohani AR, Hasserjian RP, et al. Diverse clinicopathologic features in human herpesvirus 8associated lymphomas lead to diagnostic problems. Am J Clin Pathol 2014; 142: 816-829.

16. Woodburn PW, Muhangi L, Hillier S, et al. Risk factors for helminth, malaria, and HIV infection in pregnancy in HIV/helminth co-infection in Kenya. PLoS Negl Trop Dis 2009; DOI: 10.1371/journal. pntd.0000644.

17. Fekadu S, Taye K, Teshome W, et al. Prevalence of parasitic infections in HIV-positive patients in southern Ethiopia: A cross-sectional study. J Infect Dev Ctries 2013; 7: 868-872.
18. Pavie J, Menotti J, Porcher RI, et al. Prevalence of opportunistic intestinal parasitic infections among HIV-infected patients with low CD4 cells counts in France in the combination antiretroviral therapy era. Int J Inf Dis 2012; 16: 677-679.

19. Rinmecit PG, Samuel A, Usman D. Intestinal parasitosis among HIV positive patients accessing healthcare in a Medical Centre in Norhtern Nigeri. Int J Curr Microbiol App Sci 2015;4:768-776.

20. Sarfati C, Bourgeois A, Menotti J. Prevalence of intestinal parasites including microsporidia in human immunodeficiency virus-infected adults in Cameroon: A cross-sectional study. Am J Trop Med Hyg 2006; 74: 162-164.

21. Walson JL, Stewart BT, Sangare L. Prevalence and correlates of helminth co-infection in Kenyan HIV-1 infected adults. Plos Negl Trop Dis 2010; DOI: 10.1371/journal.pntd.0000644.

22. Adams VJ, Markus MB, Adams JA, et al. Paradoxical helminthiasis and giardiasis in Cape Town, South Africa: epidemiology and control. Afr Heal Sci 2005; 5: 276-280.

23. Brown M, Kizza M, Watera C, et al. Helminth infection is not associated with faster progression of HIV disease in coinfected adults in Uganda. J Infect Dis 2004;190: 1869-1879.

24. Tian LI, Chen JX, Wang TP, et al. Co-infection of HIV and intestinal parasites in rural area of China. Parasit Vectors 2012; DOI: 10.1186/1756-3305-5-36.

25. Assefa S, Erko B, Medhin G. Intestinal parasitic infections in relation to HIV/AIDS status, diarrhea and CD4 T-cell count. BMC Inf Dis 2009; DOI: 10.1186/1471-2334-9-155.

26. Borkow G, Bentwich Z. Symptomatic immune activation associated with symptomatic helminthic and human immunodeficiency virus infections: role of hyporesponsiveness and anergy. Clin Microbiol Rev 2004; 17: 1012-1030.

27. Babatunde SK, Salami AK, Fabiyi JP, et al. Prevalence of intestinal parasitic infestation in HIV seropositive and seronegative patients in Ilorin. Nigeria Ann Afr Med 2007; 9: 123-128.

28. Bava AJ, Troncoso AR. Strongyloides stercoralis hyperinfection in a patient with AIDS. J Int Assoc Phys AIDS Care (Chic) 2009; 8: 235-238.

29. Chachange MK, Geldmacher K, et al. Helminthassociated systemic immune activation and HIV co-receptor expression: response to albendazole/ praziquantel treatment. Plos Negl Trop Dis 2014; DOI: 10.1371/journal.pntd.0002755, 81-13.

30. Wiwanitkit V. Intestinal parasitic infections in Thai HIV-infected patients with different immunity status. BMC Gastroenterology 2001; 1: 1-3.

31. KalinkovichA, Borkow G, Weisman Z, etal. Increased CCR5 and CXCR4 expression in Ethiopians living in Israel: environmental and constitutive factors. Clin Immunol 2001; 100:107-117. 
32. Chou A, Serpa JA. Eosinophilia in patients infected with human immunodeficiency virus. Curr HIV/ AIDS Rep2015; 12: 313-316.

33. Yazdanbakhsh MBA, Maizels RM. Th2 responses without atopy: immunoregulation in chronic helminth infections and reduced allergic disease. Trends Immunol 2001; 22: 372-377.

34. Lopalco L. CCR5: from natural resistance to a new anti-HIV strategy. Viruses 2010; 2: 574-600.

35. Alemu A, Shiferaw Y, Getnet G, et al. Opportunistic and other intestinal parasites among HIV/AIDS patients attending Gambi higher clinic in Bahir Dar city, North West Ethiopia. Asian Pac J Trop Med 2011; 4: 661-665.

36. McElroy MD, Elrefaei M, Jones N, et al. Coinfection with Schistosoma mansoni is associated with decreased HIV-specific cytolysis and increased IL10 production. J Immunol 2005; 174: 5119-5123.

37. KalinkovichA, Borkow G, WeismanZ, et al. Increased CCR5 and CXCR4 expression in Ethiopians living in Israel: environmental and constitutive factors. Clin Immunol 2001; 100: 107-117.

38. Mkhize-Kwitshana Z., Taylor M, Jooste P, et al. The influence of different helminth infection phenotypes on immune responses against HIV in co-infected adults in South Africa. BMC Infect Dis 2011; 11: 1-11.

39. Mulu A, Anagaw B, Gelaw A, et al. Effect of deworming on Th2 immune response during HIV-helminths co-infection. J Transl Med 2015; 13: 1-8.

40. Pastrana DV, Raghavan N, FitzGerald P, et al. Filarial nematode parasites secrete a homologue of the human cytokine macrophage migration inhibitory factor. Infect Immun 1998; 66: 5955-5963.

41. Gelaw A, Abate E, Idh J, et al. Plasma IgE level and eosinophil count in smear positive tuberculosis patients with and without helminthic infections at Gondar University Hospital, North-west Ethiopia. Eur J Exp Biol 2012; 2: 2010-2014.

42. Kassu A, Tsegaye A, Wolday D, et al. Role of incidental and/or cured intestinal parasitic infections on profile of CD4+ and CD8 $+\mathrm{T}$ cell subsets and activation status in HIV-1 infected and uninfected adult Ethiopians. Clin Exp Immunol 2003; 132: 113-119.

43. Mkhize-Kwitshana ZL, Mabaso MLH, Walzl G. Proliferative capacity and cytokine production by cells of HIV-infected and uninfected adults with different helminth infection phenotypes in South Africa. BMC Inf Dis 2014; 14: 1-13.

44. Kaminsky RG, Soto RJ, Campa A, et al. Intestinal parasitic infections and eosinophilia in an human immunedeficiency virus positive population in Honduras. Mem Inst Oswaldo Cruz 2005; 99: 773 778.
45. Mazigo HD., Dunne DW., Wilson S, et al. Coinfection with Schistosoma mansoni and Human Immunodeficiency Virus-1 (HIV-1) among residents of fishing villages of north-western Tanzania. Parasit Vectors 2014; DOI: 10.1186/s13071-014-0587-27.

46. Hotez PJ, Kamath A. Neglected tropical diseases in sub-Saharan Africa: review of their prevalence, distribution, and disease burden. PLoS Negl Trop Dis 2009; DOI: 10.1371/journal.pntd.0000412.

47. Fontanet AL, Woldemichael T, Sahlu T, et al. Epidemiology of HIV and S. mansoni infections among sugar-estate residents in Ethiopia. Annals Trop Med Parasitol 2000; 94: 145-155.

48. Mazigo HD., Dunne DW, Wilson S, et al. Coinfection with Schistosoma mansoni and Human Immunodeficiency Virus-1 (HIV-1) among residents of fishing villages of north-western Tanzania. Parasit Vectors 2014; DOI: 10.1186/ s13071-014-0587-27.

49. Lawn SD., Butera ST., Folks TM. Contribution of immune activation to the pathogenesis and transmission of human immunodeficiency virus type 1 infection. Clin Microb Rev 2001; 14: 753 -777.

50. Lawn SD, Karanja DM, Mwinzia P, et al. The effect of treatment of schistosomiasis on blood plasma HIV-1 RNA concentrations in coinfected individuals. AIDS 2000; 14: 2437-2443.

51. Zanoni BC, Phungula T, Zanoni HM, et al. Risk factors associated with increased mortality among HIV infected children initiating antiretroviral therapy (ART) in South Africa. PLoS One 2011; DOI: 10.1371/journal.pone.0022706.

52. Ayash-Rashkovsky M, Cheninel AL, Steele LN, et al. Coinfection with Schistosoma mansoni reactivates viremia in rhesus macaques with chronic simian-human immunodeficiency virus clade C infection. Infect Immun 2001; 75:1751-56.

53. Sabah AA, Fletcher C, Webbe G, et al. Schistosoma mansoni: reduced efficacy of chemotherapy in infected T-cell deprived mice. Exp Parasitol 1985; 60: 348-54.

54. Karanja DM, Colley DG, Nahlen BL, et al. Studies on schistosomiasis in western Kenya: I. Evidence for immune-facilitated excretion of schistosome eggs from patients with Schistosoma mansoni and human immunodeficiency virus coinfections. Am J Trop Med Hyg 1997; 56: 515-21.

55. Nkenfou CN, Nana CT, Payne WK. Intestinal parasitic infections in HIV infected and noninfected patients in a low HIV prevalence region, West-Cameroon. PLoS One 2013; 8: 1-6.

56. Jourdan PM, Roald B, Poggensee G, et al. Increased vascularity in cervicovaginal mucosa with Schistosoma haematobium infection. PLoS Negl Trop Dis 2011; DOI: 10.1371/journal. pntd.0001170. 
57. Jourdan PM., Holmen SD, Gundersen SG, Eet al. HIV target cells in Schistosoma haematobium infected female genital mucosa. Am J Trop Med Hyg 2011; 85: 1060-1064.

58. Sanya RE, Muhangi L, Nampijja $M$, et al. Schistosoma mansoni and HIV infection in a Ugandan population with high HIV and helminth prevalence. Trop Med Internat Health 2015; 10: 1-8.

59. Mwinzi PMN, Karanja DMS, Colley DG, et al. Cellular immune responses of schistosomiasis patients are altered by human immunodeficiency virus type 1 coinfection. J Inf Dis 2001; 184: 488-496.

60. Adeleke OA, Yogeswaran P, Wright G. Intestinal helminth infections amongst HIV-infected adults in Mthatha General Hospital, South Africa. Afr J Prim Health Care Fam Med 2015; DOI: 10.4102/ phcfm.v7i1.910.

61. Kassu A, Mohammad A, Fujimaki Y, et al. Serum IgE levels of tuberculosis patients in a tropical setup with high prevalence of HIV and intestinal parasitoses. Clin Exp Immunol 2004; 138: 122-127.

62. Kassu A, Ota F. Fujimaki Y, et al. Levels of serum HIV-1 RNA viral load in tuberculosis patients with or without intestinal parasites during treatment of tuberculosis in Gondar, Ethiopia. Ethiop J Heal Biomed Sci 2008; 1: 5-13.

63. Kallestrup P, Zinyama R, Gomo E, et al. Schistosomiasis and HIV-1 infection in rural Zimbabwe: implications of coinfection for excretion of eggs. J Infect Dis 2005; 191: 13111320 (2005).

64. Bhaijee F, Subramony C, Tang S, et al. Human immunodeficiency virus-associated gastrointestinal disease: common endoscopic biopsy diagnoses. Patholog Res Int 2011; 26: 1-8.

65. Matera G, Focà A, Scallise C, et al. Ascaris lumbricoides-induced suppression of total and specific IgE responses in atopic subjects is interleukin 10-independent and associated with an increase of CD25(+) cells. Diagn Microbiol Infect Dis 2008; 62: 280-286.

66. Olsen A, Lieshout L, Marti H, et al. Strongyloidiasisthe most neglected of the neglected tropical diseases?. Trans R Soc Trop Med Hyg 2009; 103; 967-972.

67. Malla N, Ahmad M, Fomda BA, et al. Serum cytokine levels in human ascariasis and toxocariasis. Parasitol Res 2006; 98: 345-348.

68. Schar F, Trostdorf1 U, Giardina F, et al. Strongyloides stercoralis: Global distribution and risk factors. Plos Neg Trop Dis 2013; DOI: 10.1371/journal.pntd.0002288.

69. Coutinho HB, Robalinho TI, Coutinho VB, et al. Immunocytochemistry of mucosal changes in patients infected with the intestinal nematode Strongyloides stercoralis. J Clin Pathol 1996; 49: 717-720.
70. Meamar AR, Rezaian M, Mohraz M, et al. Strongyloides stercoralis hyper-infection syndrome in HIV+/AIDS patients in Iran. Parasitol Res 2007; 101: 663-665.

71. Orem J, Mayanja B, Okongo M, et al. Strongyloides stercoralis hyperinfection in a patient with AIDS in Uganda successfully treated with ivermectin. Clin Infect Dis 2003; 37: 152-153.

72. Romero-Cabello P, Gómez VJ, Hernández J, et al. Hyperinfection with Strongyloides stercoralis. BMJ Case Reports 2012; 10: 1-5.

73. Vaiyavatjamai P, Boitano JJ., Techasintana P, et al. Immunocompromised group differences in the presentation of intestinal strongyloidasis. Jpn J Infect Dis 2008; 61: 5-8.

74. Da'dara A, Harn DA. Elimination of helminth infection restores HIV-1C vaccine specific T cell responses independent of helminth-induced IL-10. Vaccine 2010; 3: 1310-1317.

75. Efraim L, Downs JA et al. Schistosomiasis and impaired response to antiretroviral therapy among hiv-infected patients in Tanzania. J Acquir Immune Defic Syndr 2013; DOI: 10.1097/ QAI.0b013e318282a1a4.

76. Modjarrad K, Zulu I, Redden DT, et al. Treatment of intestinal helminths does not reduce plasma concentrations of HIV-1 RNA in coinfected Zambian adults. J Infect Dis 2005; 192: 1277-1283.

77. Sangaré LR, Herrin BR, John-Stewart G, et al. Species-specific treatment effects of helminth/ hiv-1 coinfection: a systematic review and metaanalysis. Parasitology 2011; 138: 1546 -1558.

78. Arndt MB, John-Stewart G, Richardson BA, et al. Impact of helminth diagnostic test performance on estimation of risk factors and outcomes in HIVpositive adults. Plos One 2013; DOI: 1371/journal. pone.0081915 8 .

79. Roka M, Goñi P, Rubio E, et al. Prevalence of intestinal parasites in HIV-positive patients on the island of Bioko, Equatorial Guinea: Its relation to sanitary conditions and socioeconomic factors. Sci Tot Environ 2012; 432: 404-411.

Received: 31.01.2018

Accepted for publication: 12.07.2018

Otrzymano: 31.01.2018 r.

Zaakceptowano do publikacji: 12.07.2018 r.

\section{Autor do korespondencji:}

Author for correspondence:

Agnieszka Pawelczyk

Zakład Immunopatologii Chorób Zakaźnych i Pasożytniczych,

Warszawski Uniwersytet Medyczny,

ul. Pawińskiego 3c; 02-106 Warszawa;

tel. 225720709 ;

e-mail: agnieszka.pawelczyk@wum.edu.pl 